\title{
Empire Broadcasting
}

$I^{N}$ $\mathrm{N}$ the field of radio communication, the last few weeks of the year 1932 were conspicuous for the inauguration of a regular broadcasting service between Great Britain and the various portions of the British Empire. The developments which took place in this connexion during 1932 are somewhat striking, and they are recorded in some detail in the B.B.C. Year Book for 1933. From the previous edition of this Year Book, it appeared that little progress was likely in connexion with the Empire broadcasting scheme drawn up by the British Broadcasting Corporation owing to lack of support by the Colonial and Imperial Conferences of 1930 , and the responsible authorities in the overseas countries concerned. In November 1931, however, the B.B.C. announced its intention of developing the Empire broadcasting scheme on its own initiative, and the rapid progress made during the ensuing twelve months is illustrated by the fact that the regular service from the new station erected at Daventry for the purpose began on December 19 .

As an aid in the development of this new broadcasting service, the B.B.C. had the benefit of about five years' experience with an experimental short wave station erected at the Marconi Company's works at Chelmsford. Owing to the fact that the distances from Great Britain to the various Dominions and Colonies are in the range $2,000-13,000$ miles, it is necessary to make use of the short wave-length band of approximately 12-60 metres for radio communication. The Chelmsford station operated on a wave-length of 25 metres, and enabled a large amount of technical data to be obtained in connexion with short wave broadcasting. A little consideration of the matter will show, however, that one transmitting station working on a single wave-length cannot provide a satisfactory Empire broadcasting service. In the first place, account must be taken of the wide differences in local time in the various countries concerned, and it is obvious that the broadcast reception must be possible in general during the leisure hours of the inhabitants of those countries. Secondly, as a result of experience, not only in broadcasting but also with ordinary telephonic and telegraphic radio communication on short waves, it is known that the choice of the best wave-length varies with the distance to be covered, and whether the portion of the earth over which the communication takes place is in sunlight or darkness. Following on the latter condition, it is frequently found that diurnal and seasonal variations in the ionosphere, without which longdistance short wave communication would apparently not be possible, make it necessary to have a choice of at least two wave-lengths in order to maintain regular communication between two fixed points. Lastly, a directive antenna system at either or both ends of the communication link, makes such a vast improvement in general efficiency that the arrangement is always employed where possible in commercial short wave communication.

Based upon the considerations outlined above, the British Empire has been divided up into five zones and the new station at Daventry is designed to supply a direct broadcasting service to listeners in each zone, a two-hour programme being given daily between 6 P.M. and midnight local time, with the hours 8-10 P.M. as a focus wherever possible. For each zone a separate antenna array has been erected at Daventry, each array being so oriented as to give a not too highly concentrated. beam of radiation in the desired direction. In the case of the first array, for Australasia, the transmission is limited to a single wave-length of $25 \cdot 5$ metres, but the radiator and reflector units of the array are reversible so that the waves can be transmitted around the earth in either direction. In the case of the other four zones, two or three wave-lengths are available as required. The approximate constitution of these zones, with the wave-lengths available, and the periods in G.M.T. at which the transmissions take place in Great Britain are given in the following table :

\begin{tabular}{|c|c|c|c|}
\hline Zone. & Countries. & $\begin{array}{l}\text { Wave-lengths } \\
\text { (metres). }\end{array}$ & $\begin{array}{l}\text { Approximate } \\
\text { programme period } \\
\text { (G.M.T.). }\end{array}$ \\
\hline 1 & $\begin{array}{l}\text { Australasia, including New } \\
\text { Zealand, Bornco, New } \\
\text { Guinea and the Paciflc }\end{array}$ & & \\
\hline & Islands & $25 \cdot 5$ & $9.30-11.30$ A.M. \\
\hline & $\begin{array}{l}\text { India, with Burma and the } \\
\text { Federated Malay States.. } \\
\text { South Africa, with East }\end{array}$ & 17,25 and 32 & $2.30-4.30$ P.M. \\
\hline 4 & $\begin{array}{l}\text { Africa, Palestine, Sudan } \\
\text { and Somaliland . } \\
\text { west Africa, Nigeria and }\end{array}$ & 14 and 32 & $6.0-8.0$ P.M. \\
\hline & $\begin{array}{l}\text { Gold Coast, with Tristan } \\
\text { da Cunha and Falkland } \\
\text { Islands }\end{array}$ & 32 and 48 & $8.0-10.0$ P.M. \\
\hline כ & $\begin{array}{l}\text { Canada, Newfoundland and } \\
\text { West Indies }\end{array}$ & 19,32 and 48 & $1.0-3.0 \mathrm{~A} . \mathrm{M}$. \\
\hline
\end{tabular}

In addition to the directional antenna arrays, six omnidirectional aerials have been provided and these will be used for transmitting any special programmes which it may be desired to receive at any hour in any part of the world.

These arrays and aerials are supplied by feeders or transmission lines from two transmitters housed in the new station building at Daventry. Each of these transmitters is of modern design and construction, and comprises a crystal-controlled master oscillator followed by the necessary frequency multiplying, modulating and energy amplifying stages: these terminate in a final amplifier which consists of four $15 \mathrm{kw}$. valves connected in push-pull arrangement, the output circuits of which are coupled to the aerial feeder.

The programme supplied through this station will comprise items largely of an original or topical nature, having entertainment or news interest of a type not normally obtainable in the countries where reception takes place. Owing to the difficulties of arranging repeat performances, particularly at the more inconvenient times shown in the above table, the B.B.C. will make extensive 
use of modern electrical methods of programme recording for use in the transmitters. As an example of the use of the station, reference may be made to the occasion of the broadcasting of the King's Christmas message on December 25 last, when the vision of Sir Ambrose Fleming and other pioneers of radio communication, of a single human voice addressing listeners over the whole surface of the earth, was realised. In addition to being transmitted by all the B.B.C. stations serving Great Britain, it was sent through the two Empire transmitters at Daventry. One of these was connected to the Indian zone array, for which zone the transmission took place at the normal time. The other short wave transmitter was operated on a wave-length of about 20 metres, and supplied an omnidirectional aerial, so as to broadcast so far as possible in all directions. In addition, the programme was recorded by Blattnerphone and used for re-transmission in the various zone programmes later in the day.

In addition to the direct reception from Daventry on listeners' private receiving sets, it is likely that the broadcasting authorities in the Dominions will arrange for the relaying of some programmes through their local stations operating on medium wave-lengths. From the point of view of the B.B.C., the whole Empire service will be experimental for a period of about six months, during which arrangements will be made to collect reports of reception from selected listeners in all parts of the Empire.
R. L. S.-R.

\section{News and Views}

\section{New Year Honours}

THE New Year Honours List includes the following names of scientific workers and others associated with seientific work: Baron: Sir Thomas Horder, Bt., senior physieian to St. Bartholomew's Hospital. Knight of the Thistle: The Right Honourable Sir Herbert Maxwell, Bt., chairman of the Royal Commission on Scottish Historical Monuments, president of the Society of Antiquaries of Scotland, 1900-13. K.C.B. : Sir Frederick Leith-Ross, chief economic adviser to His Majesty's Government. K.C.I.E. : Major-General J. W. D. Megaw, Director-General of the Indian Medical Service. K.C.V.O.: Mr. F. J. Willans, surgeon apothecary to H.M. Household at Sandringham. Knights : Mr. C. A. Cochrane, chairman of the Council of Armstrong College, University of Durham. Mr. H. H. Dalrymple-Hay, consulting engineer, for his inventions and services in connexion with the construction of tube railways. Prof. F. T. G. Hobday, Principal and Dean of the Royal Veterinary College. Mr. A. J. C. Huddleston, lately economic adviser to the Sudan Government. Mr. J. L. McKelvey, for services to surgery in the Commonwealth of Australia. Mr. E. R. D. Maclagan, Director and Secretary, Victoria and Albert Museum. Mr. W. Perry, president of the Royal Agricultural Society, New Zealand. Mr. R. S. Rait, Prineipal and Vice-Chancellor of the University of Glasgow since 1929. C.H.: Rev. John Scott Lidgett, president of the Methodist Church, Vice-Chancellor of the University of London in 1930-31 and 1931-32. C.M.G.: Dr. J. J. C. Bradfield, Government engineer, Sydney Harbour Bridge, State of New South Wales. Prof. D. B. Copland, professor of commerce, University of Melbourne. Mr. L. Ennis, constructing engineer for Messrs. Dorman, Long and Co., Sydney Harbour Bridge, New South Wales. Mr. W. B. Johnson, director of Medical and Sanitary Service, Nigeria. Mr. W. J. U. Wooleock, formerly general manager of the Association of British Chemical Manufacturers, chairman of the Committee of Non-official Advisers associated with the industrial advisers of the United Kingdom delegation at the Ottawa Conference. C.I.E. : MajorGen. W. C. H. Forster, Surgeon-General with the Government of Bombay. Lieut.-Col. R. B. Seymour Sewell, director of the Zoological Survey of India. Mr. C. G. Trevor, chief conservator of forests, Punjab and North-West Frontier Province. Col. J. N. Walker, director of the Medical Department and Sanitary Commissioner, his Exalted Highness the Nizam's Government, Hyderabad, Deccan. C.B.E. : Mrs. Alice Baker, one of the founders of the Thomas Baker, Alice Baker, and Eleanor Shaw Medical Research Institute, Melbourne, Commonwealth of Australia. Dr. F. H. A. Marshall, reader in agrieultural physiology in the University of Cambridge. Dr. S. W. Smith, ehief assayer, Royal Mint, and president of the Institute of Mining and Metallurgy. Dr. H. A. Tempany, director of agriculture, Straits Settlements and Federated Malay States. Prof. H. E. Whitfeld, Vice-Chancellor of the University, State of Western Australia. O.B.E. : Dr. J. T. Bradley, chief medical officer, Seychelles. Mr. A. V. Elsden, War Department chemist, Royal Arsenal, Woolwich. Mr. A. McCallum, senior inspector for agricultural education, Department of Agriculture for Scotland. Mitharam Pribhdas Mathrani, executive engineer, Left Works Division, Lloyd Barrage Circle, Sukkur, Bombay. Dr. S. A. Neave, assistant director, Imperial Institute of Entomology. Mr. J. Smith, director of animal health and acting secretary for agriculture, Northern Rhodesia. Mr. H. W. O. Taylor, executive engineer, Right Works Division, Lloyd Barrage Circle, Sukkur, Bombay. Mr. R. S. Taylor, principal medical officer, Somaliland Protectorate. M.B.E. : Mr. J. Coelho, assistant Crown surveyor and assistant engineer, Public Works Department, Gibraltar. Mr. W. M. Schutte, agricultural engineer to the Government of Bombay. Mr. H. N. Williams, assistant engineer, Irrigation Department, Iraq.

\section{Calendar of Nature Topics}

For the past nine years calendars have been published in our columns recording week by week notes of historic interest relating to people and 